\title{
KINETICS AND MECHANISTIC STUDY OF OXIDATION OF AMOXICILLIN BY CHLORAMINE-T IN ACID MEDIUM
}

\author{
M. S. VEENA ${ }^{1}$, M. K. PRASHANTH ${ }^{2}$, K. YOGESH KUMAR ${ }^{3}$, H. B. MURALIDHARA, ,* Y. ARTHOBA NAYAKA \\ ${ }^{1}$ Centre for Nanosciences, Department of Chemistry, K.S. Institute of Technology, Bangalore 560 062, India. \\ ${ }^{2}$ Department of Chemistry, P.N.S. Institute of Technology, Bangalore 562 123, India. \\ ${ }^{3}$ Department of Chemistry, School of Engineering and Technology, Jain University, Bangalore 562 112, India. \\ ${ }^{4, *}$ Centre for Emerging Technologies, Jain University, Bangalore 562 112, India. \\ ${ }^{5}$ Department of PG Studies and Research in Chemistry, School of Chemical Sciences, Kuvempu University, Shankaraghatta 577451 , India.
}

\begin{abstract}
This spectroscopic study presents the kinetics and degradation pathways of oxidation of amoxicillin (AMOX) by chloramines-T (CAT) in acidic medium at a constant ionic strength of $0.105 \mathrm{~mol} \mathrm{dm}^{-3}$ at $298 \mathrm{~K}$. Reaction between AMOX and CAT in acidic medium exhibits 1:1 stoichiometry (AMOX:CAT). The reaction is of a first-order in both [CAT] and [AMOX]. The order with respect to acid concentration was fractional. The effects of added products, ionic strength and dielectric constant have been studied. The main oxidation product of AMOX was identified by IR, ${ }^{1} \mathrm{H}$ NMR and mass spectra. The reaction constants involved in the different steps of the mechanisms were calculated. Activation parameters with respect to slow step of the mechanisms were computed and discussed.
\end{abstract}

Keywords: Amoxicillin, Chloramines-T, Kinetics, Mechanistic, Oxidation.

\section{INTRODUCTION}

Amoxicillin (AMOX, Fig. 1) semi-synthetic drug belongs to a class of antibiotics called the Penicillins ( $\beta$-lactam antibiotics). The chemical structure of AMOX consists of d-4-hydroxyphenylglycine side chain attached to 6 -aminopenicillanic acid moiety. AMOX is usually the drug of choice within the class because of its better absorbed than other $\beta$-lactam antibiotics. It acts by inhibiting the synthesis of bacterial cell wall. It inhibits cross-linkage between the peptidoglycan polymer chains that make up a major component of cell walls of both Gram-positive and Gram-negative bacteria. The therapeutic importance of this compound justifies that, necessary to develop spectrophotometrickinetic method.<smiles>CC1(C)SC2C(NC(=O)C(N)c3ccc(O)cc3)C(=O)N2C1C(=O)O</smiles>

Figure 1. Structure of AMOX.

AMOX is official in IP, BP, Eur Pharmacopoeia and USP [1-4]. The official method involves the non-aqueous titrimetric method. Among the various methods available for the estimation of AMOX such as fluorometry, chemiluminescence, voltammetry, HPLC, spectrophotometry method is still a preferred technique due to its simplicity and economy [5-8].

Chloramine-T (CAT) is the most important member of organic halo-amine family and behaves as an oxidizing agent in both acidic and alkaline media. It is versatile oxidizing agent and has shown a variety of kinetic results due to formation of its various oxidizing species depending upon $\mathrm{pH}$ of the medium [9]. Compounds such as hypochlorite and CAT can act as a source of chlorine; they are used in disinfection of drinking water. As a result, CAT can find its way into the animal stomach, including that of human [10]. Ingested amoxicillin drugs can react with CAT under acidic condition in the stomach. Therefore there was a need for understanding the oxidation mechanism of the drug in acidic medium so that the study could throw some light on the fate of the drug in the biological systems in vivo.

Studies on AMOX oxidation involving many oxidants have been reported. In the past decades, Fenton oxidation or Fenton like processes have been investigated for antibiotics degradation and biodegradability improvement, such as $\mathrm{Fe}^{2+} / \mathrm{H}_{2} \mathrm{O}_{2}, \mathrm{Fe}^{3+} / \mathrm{H}_{2} \mathrm{O}_{2}, \mathrm{Fe}^{2+} / \mathrm{H}_{2} \mathrm{O}_{2} / \mathrm{UV}$ and $\mathrm{Fe}^{3+} / \mathrm{H}_{2} \mathrm{O}_{2} / \mathrm{UV}$ [11]. Filiz et al., [12] investigated oxidation of AMOX by Fenton's reagent treatment, Sharma et al., [13] investigated Oxidation of $\beta$-lactam antibiotics by ferrateVI. Rizzo et al., [14] investigated degradation and mineralization kinetics of antibiotics present in treated wastewater effluent containing amoxicillin using $\mathrm{TiO}_{2}$ photocatalysis, but no studies are made from the kinetics and mechanistic view point on the oxidation of AMOX by CAT. Hence, the present work is slated to report the UV-visible spectrophotometrically monitored kinetics of oxidation of AMOX by CAT in acidic medium in order to elucidate the reaction mechanism.

\section{EXPERIMENTAL}

Apparatus

All the spectrophotometric measurements were performed using an Ocean optics Model UV-visible digital Spectrophotometer provided with 1-cm matched quartz cells. Elemental analysis $(\mathrm{C}, \mathrm{H}, \mathrm{N})$ was determined using a Carlo-Erba 1160 elemental analyzer. IR spectra were recorded on a JASCO FTIR-8400 spectrophotometer using $\mathrm{KBr}$. The ${ }^{1} \mathrm{H}-\mathrm{NMR}$ spectra were recorded on a Varian AC 400 spectrometer instrument in DMSO- $d_{6}$ using TMS as the internal standard. Low resolution ESI-MS spectra were obtained on a Varian 1200L model mass spectrometer (solvent: $\mathrm{CH}_{3} \mathrm{OH}$ ).

Reagents and Materials

All chemicals used were of analytical grade. Chloramine-T (CAT) (S.D. Fine Chem Ltd.) was used without further purification by freshly preparing their solution in double distilled water and standardized iodometrically. Sodiumperchlorate monohydrate $\left(\mathrm{NaClO}_{4}\right)$ (Hi Media) was used without further purification by preparing solution appropriate in double distilled water. AMX was purchased from Sigma Aldrich. The solubility of AMOX was checked since it was sparingly soluble in water; hence the stock solution was made by dissolving the drug with $1 \mathrm{ml}$ of methanol along with double distilled water. Double distilled water was used for preparing aqueous solutions.

Kinetic measurement

Kinetic runs were followed under pseudo-first order conditions with the AMOX concentration in excess over CAT. Solutions containing appropriate amounts of $\mathrm{AMOX}, \mathrm{HCl}, \mathrm{NaClO}_{4}$ and water (to keep the total volume constant for all the runs) were taken in a conical flask and kept on water bath at $25^{\circ} \mathrm{C} \pm 1$. A measured amount of CAT solution was taken in another conical flask and kept on the same water bath. After few minutes the CAT solution rapidly added to the reaction mixture and shaken well for uniform concentration. The progress of reaction was followed spectrophotometrically at $350 \mathrm{~nm}$ by monitoring the changes in absorbance. It was verified that there is a negligible interference from other species present in the reaction mixture at this wavelength. The reaction was followed to more than $80 \%$ completion of the reaction. Plots of $\log ($ absorbance $)$ versus time lead to the first order rate constant $(\mathrm{k})$. 


\section{RESULTS}

Stoichiometry and product analysis

Different sets of reaction mixtures containing different concentrations of AMOX and CAT in presence of $\mathrm{HCl}$ were equilibrated at $298 \mathrm{~K}$ for $24 \mathrm{~h}$.

The unreacted concentration of CAT in the reaction mixture was estimated by spectrophotometrically at $350 \mathrm{~nm}$. The results indicated that 1:1 stoichiometry (AMOX:CAT) is represented by equation,

Amoxicillin $+\mathrm{TsNCINa} \stackrel{\mathrm{HCl}}{\longrightarrow} \mathrm{C}_{8} \mathrm{H}_{11} \mathrm{NO}_{4} \mathrm{~S}+\mathrm{TsNH}_{2}+\mathrm{Na}^{+}+\mathrm{Cl}^{-}$

where Chloramine- $\mathrm{T}$ is TsNClNa with $\mathrm{Ts}=\mathrm{p}-\mathrm{MeC}_{6} \mathrm{H}_{4} \mathrm{SO}_{2}$.

The products in the reaction mixture were extracted several times with diethyl ether. The oxidized form of AMOX was identified (Compound 1 and 2). The nature of the product was confirmed by its UV, Cyclic voltammetry, IR, ${ }^{1} \mathrm{H}$ NMR and mass spectra.

The absorbance of CAT seen at $\lambda=292 \mathrm{~nm}$, absorbance of AMOX showed at $\lambda_{\max }=288 \mathrm{~nm}$ [15] and the absorbance of compound (2) showed in two region 356 and $300 \mathrm{~nm}$ due to conjugation in the structure. Voltammetric method was used for determination of amoxicillin in micellar media at carbon paste electrode (CPE). Cyclic voltammogram obtained for electrochemical oxidation of $5 \mathrm{mM}$ AMOX in $0.2 \mathrm{M}$ acetate buffer (pH 3.75) in $3 \mathrm{mM}$ SLS (sodium lauryl sulfate) on CPE are shown in Fig. 2. The Oxidation peak of amoxicillin at $0.896 \mathrm{~V}$ showed that the drug undergoes oxidation. The IR spectra revealed stretching band at $3256 \mathrm{~cm}^{-1}$, confirm the presence of $\mathrm{NH}_{2}$, while $-\mathrm{S}=\mathrm{O}$ group demonstrated a band at $1380 \mathrm{~cm}^{-1}$. The ${ }^{1} \mathrm{H}$ NMR spectra showed the singlet of methyl $\left(-\mathrm{CH}_{3}\right)$ at $2.353 \mathrm{ppm}$, while the singlet at 7.225 ppm $(2 \mathrm{H})$ indicated the amine $\left(\mathrm{NH}_{2}\right)$ group. The multi-signals within the range $7.333-7.698 \mathrm{ppm}$ are assigned to the aromatic protons. The mass spectra of compound 1 and 2 showed molecular ion peak $\mathrm{M}^{+}$at 217 and 171 , respectively corresponding to their molecular formula.

6-Hydroxy-3,3-dimethyl-7-oxo-4-thia-1-azabicyclo[3.2.0] heptane-2carboxylic acid (1): Analytical data: for $\mathrm{C}_{\mathrm{H}} \mathrm{H}_{1} \mathrm{NOS}$ : C, 44.23; H, 5.10; N, 6.45; O, 29.46; S, 14.76. found: $\mathrm{C}, 44.13 ; \mathrm{H}, 5.01 ; \mathrm{N}, 6.25 ; \mathrm{O}, 29.46 ; \mathrm{S}, 14.59$. MS, m/z: $217\left(\mathrm{M}^{+}\right)$.

4-Methylbenzenesulfonamide (2): Analytical data: for $\mathrm{C}_{7} \mathrm{H}_{9} \mathrm{NO}_{2} \mathrm{~S}$ : C, 49.10, H, 5.30, N, 8.18, S, 18.73. found: C, 49.01, H, 5.17, N, 8.07, S, 18.61 . ${ }^{1} \mathrm{H}$ NMR (300 MHz, DMSO- $\left.d_{6}\right) \delta: 2.353\left(\mathrm{~s}, 3 \mathrm{H}, \mathrm{CH}_{3}\right), 7.225\left(\mathrm{~s}, 2 \mathrm{H}, \mathrm{NH}_{2}\right)$, 7.333-7.698 (m, 4H, Ar-H). IR (KBR, $\left.\mathrm{cm}^{-1}\right): 3256\left(\mathrm{NH}_{2}\right), 1380$ (S-O). MS, $\mathrm{m} / \mathrm{z}: 171\left(\mathrm{M}^{+}\right)$.

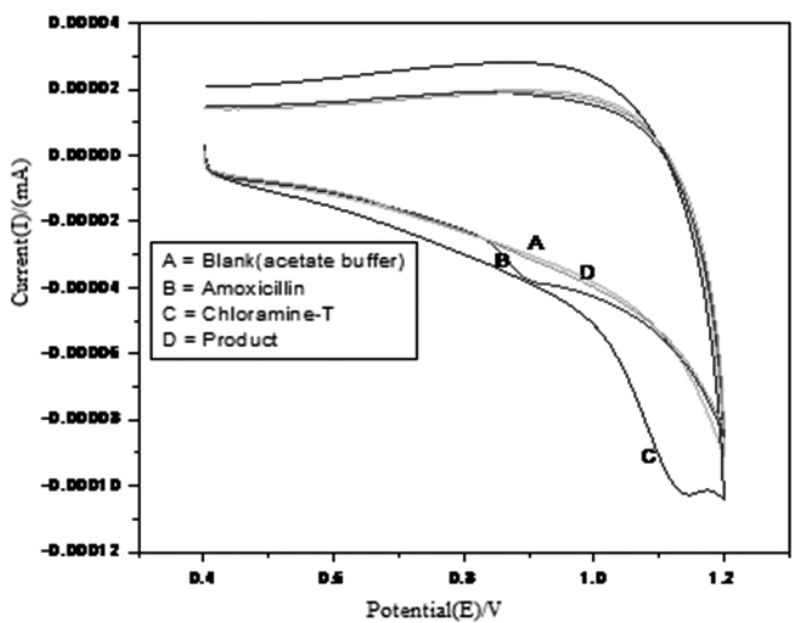

Figure 2. Cyclic Voltammogram, $A=0.2 \mathrm{M}$ acetate buffer $+3 \mathrm{mM}$ sodium lauryl sulphate (SLS), $\mathrm{B}=5 \mathrm{mM}$ Amoxicillin, $\mathrm{C}=1 \mathrm{mM}$ Chloramine- $\mathrm{T}$ and $\mathrm{D}=1$ $\mathrm{mM}$ Product in acetate buffer $+3 \mathrm{mM}$ sodium lauryl sulphate (SLS), as anionic surfactant at $\mathrm{pH}=3.75$. Scan rate at $0.05 \mathrm{v} / \mathrm{s}$ on Carbon paste electrode

\section{Reaction order}

The kinetics of oxidation of AMOX by CAT was investigated under pseudo first-order conditions of [AMOX] $>$ [CAT] at various concentrations of the reactants in acidic solution at $298 \mathrm{~K}$. Total ionic strength was maintained for $1.45 \mathrm{M}$ using sodium perchlorate.

\section{Effect of [Oxidant]}

The oxidation of AMOX by CAT was kinetically investigated at different concentrations of oxidant $\left(1.5 \times 10^{-4}\right.$ to $\left.6.0 \times 10^{-4} \mathrm{M}\right)$, with all other reaction condition kept constant. The rate constant $\mathrm{k}$ was determined from the $\log$ of absorbance versus time plot. The plots were linear up to $85 \%$ completion of reaction. An increase in [CAT] leads to an increase in the $\mathrm{k}$ values. A plot of log $\mathrm{k}$ versus $\log [\mathrm{CAT}]$ was linear with slope of 1.16 (Table 1, Fig. 3) showing first order dependence of the rate on [CAT]. The values of $\mathrm{k}$ are shown in Table 1.

Table 1. Effects of Varying Reactant Concentrations on the Reaction Rate.

\begin{tabular}{|c|c|c|c|c|}
\hline $\begin{array}{c}10^{4}[\mathrm{CAT}] \\
\left(\mathrm{mol} \mathrm{dm}^{-3}\right)\end{array}$ & $\begin{array}{c}10^{3}[\mathrm{AMOX}] \\
\left(\mathrm{mol} \mathrm{dm}^{-3}\right)\end{array}$ & $\begin{array}{c}10^{4}[\mathrm{HCl}] \\
\left(\mathrm{mol} \mathrm{dm}^{-3}\right)\end{array}$ & $\begin{array}{c}{\left[\mathrm{NaClO}_{4}\right]} \\
\left(\mathrm{mol} \mathrm{dm}^{-3}\right)\end{array}$ & $\begin{array}{c}10^{3} \mathrm{k} \\
\left(\mathrm{S}^{-1}\right)\end{array}$ \\
\hline 1.5 & 3.0 & 1.0 & 1.45 & 1.0 \\
\hline 3.0 & 3.0 & 1.0 & 1.45 & 2.5 \\
\hline 4.5 & 3.0 & 1.0 & 1.45 & 4.5 \\
\hline 6.0 & 3.0 & 1.0 & 1.45 & 2.5 \\
\hline 3.0 & 3.0 & 1.0 & 1.45 & 4.25 \\
\hline 3.0 & 4.5 & 1.0 & 1.45 & 3.75 \\
\hline 3.0 & 6.0 & 1.0 & 1.45 & 2.25 \\
\hline 3.0 & 3.0 & 0.5 & 1.45 & 2.25 \\
\hline 3.0 & 3.0 & 1.0 & 1.45 & 2.0 \\
\hline 3.0 & 3.0 & 1.5 & 1.45 & 2.25 \\
\hline 3.0 & 3.0 & 1.0 & 0.072 & 5.76 \\
\hline 3.0 & 3.0 & 1.0 & 0.145 & 3.5 \\
\hline 3.0 & 3.0 & 1.0 & 0.217 & 2.5 \\
\hline
\end{tabular}

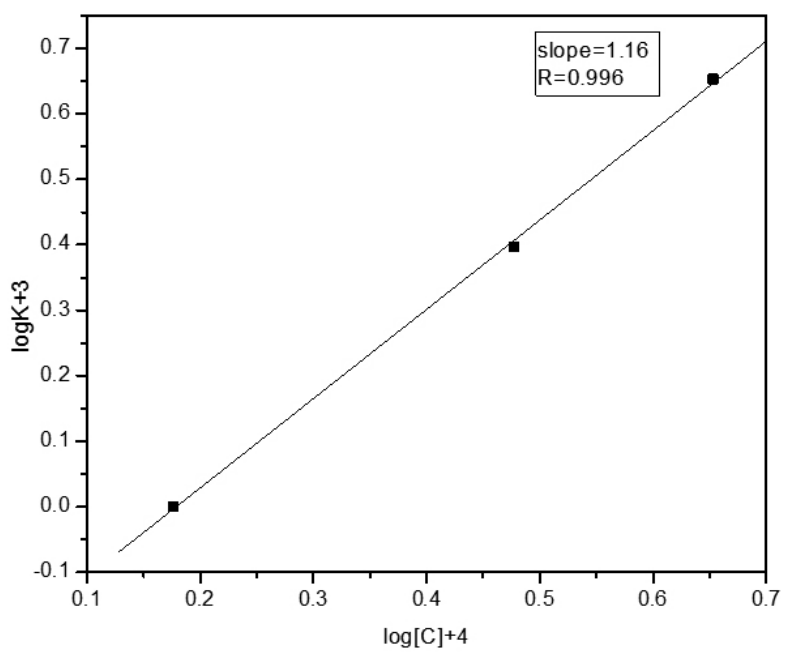

Figure 3. Effect of varying concentration of $\mathrm{CAT}$ on reaction rate [AMOX] $\left.=3.0 \times 10^{-3} \mathrm{~mol} \mathrm{dm}^{-3} ; \mathrm{HCl}\right]=1.0 \times 10^{-4} \mathrm{~mol} \mathrm{dm}^{-3}$

\section{Effect of [AMOX]}

The kinetic runs were carried out with increase in the substrate concentration $\left(3.0 \times 10^{-3}\right.$ to $\left.7.5 \times 10^{-3} \mathrm{M}\right)$ at all other constant reaction conditions. The absorbance of the product increased with increase in concentration of AMOX. A plot of log k vs. log [AMOX] was linear with a slope of 0.913 indicating first-order dependence of the rate on [AMOX] (Table 1, Fig. 4).

\section{Effect of [HCl]}

The reaction rates were measure with varying $[\mathrm{HCl}]\left(0.5 \times 10^{-4}\right.$ to $1.5 \times 10^{-4}$ M) with all other reaction conditions kept constant. The rate of the reaction increased with an increase in $[\mathrm{HCl}]$ (Table 1). A plot of log k vs. $\log [\mathrm{HCl}]$ was linear (Fig. 5) with a slope of 0.289 indicating a fractional order dependence on $\left[\mathrm{H}^{+}\right]$. 


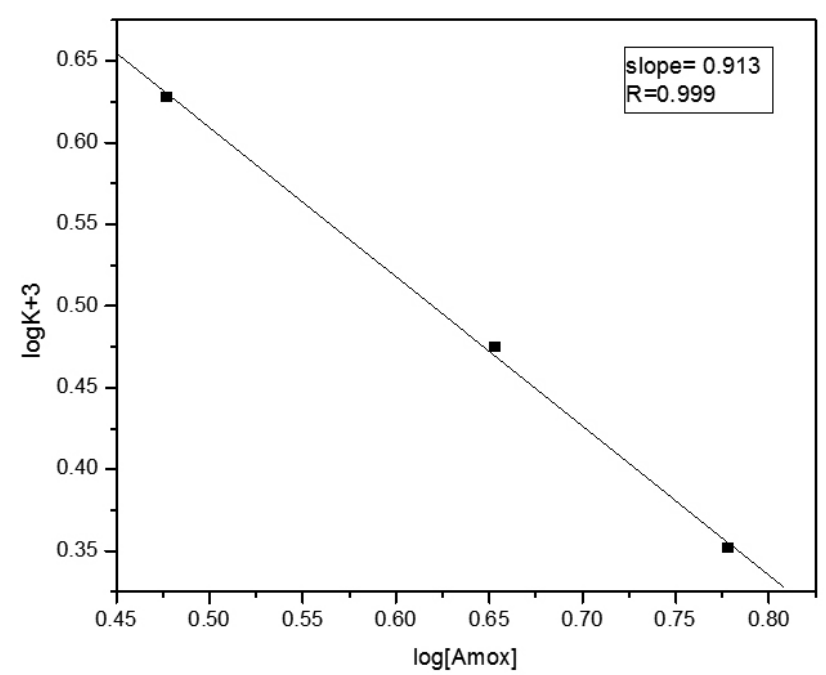

Figure 4. Effect of varying concentration of AMOX on reaction rate $[\mathrm{CAT}]=3.0 \times 10^{-4} \mathrm{~mol} \mathrm{dm}^{-3} ;[\mathrm{HCl}]=1.0 \times 10^{-4} \mathrm{~mol} \mathrm{dm}^{-3}$

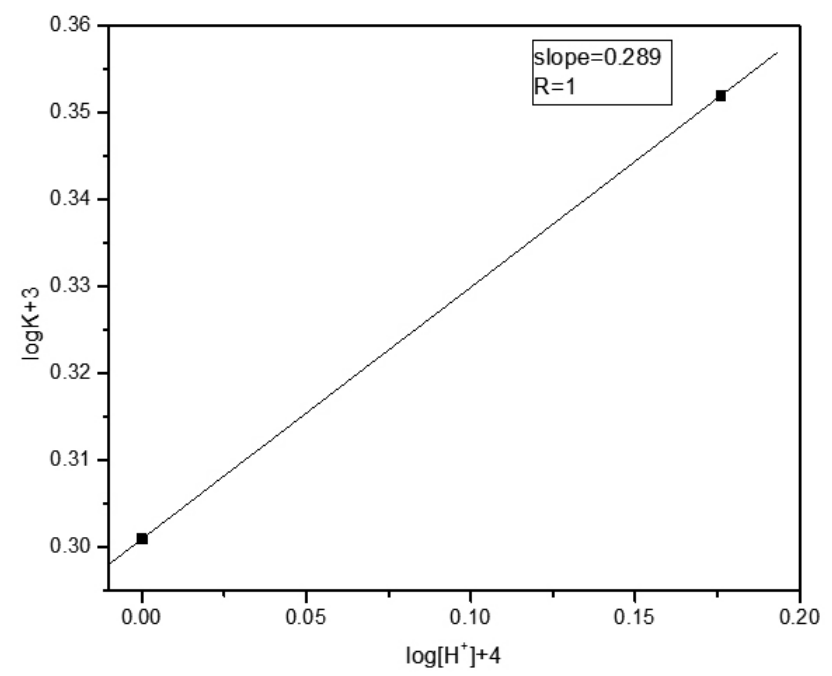

Figure 5. Effect of $\mathrm{H}^{+}$ion concentration on the oxidation of Amoxicillin $[\mathrm{AMOX}]=3.0 \times 10^{-3} \mathrm{~mol} \mathrm{dm}^{-3} ;[\mathrm{CAT}]=3.0 \times 10^{-4} \mathrm{~mol} \mathrm{dm}^{-3}$

\section{Effect of $\left[\mathrm{NaClO}_{4}\right]$}

Increase in concentration of $\mathrm{NaClO}_{4}$ doesn't affect much on reaction rate (Table 1). A plot of log $\mathrm{k}$ versus $\log \left[\mathrm{NaClO}_{4}\right]$ was linear with a negative slope of 0.75 (Fig. 6) indicating that non-ionic species being involved in the rate determining step.

\section{Effect of dielectric permittivity of the medium}

In order to determine the effect of dielectric permittivity of the medium on rate, the oxidation of AMOX by CAT studied in methanol of various compositions. The rate of reaction increased slightly with increase in methanol content $(0-15 \% \mathrm{v} / \mathrm{v})$. A plot of $\log \mathrm{k}$ versus $1 / \mathrm{D}$ (D is the dielectric permittivity of the medium) gave a straight line with positive slope (Table 2, Fig. 7). Blank experiments with methanol indicated that oxidation of methanol by CAT was negligible under the experimental conditions employed.

Table 2. Effect of dielectric constant of the medium.

\begin{tabular}{|c|c|c|}
\hline$[\mathrm{MeOH}](\% \mathrm{v} / \mathrm{v})$ & $10^{2} / \mathrm{D}$ & $10^{3} \mathrm{k}\left(\mathrm{S}^{-1}\right)$ \\
\hline 0 & 1.27 & 3.5 \\
\hline 5 & 1.31 & 2.5 \\
\hline 10 & 1.35 & 3.5 \\
\hline 15 & 1.39 & 5.0 \\
\hline
\end{tabular}

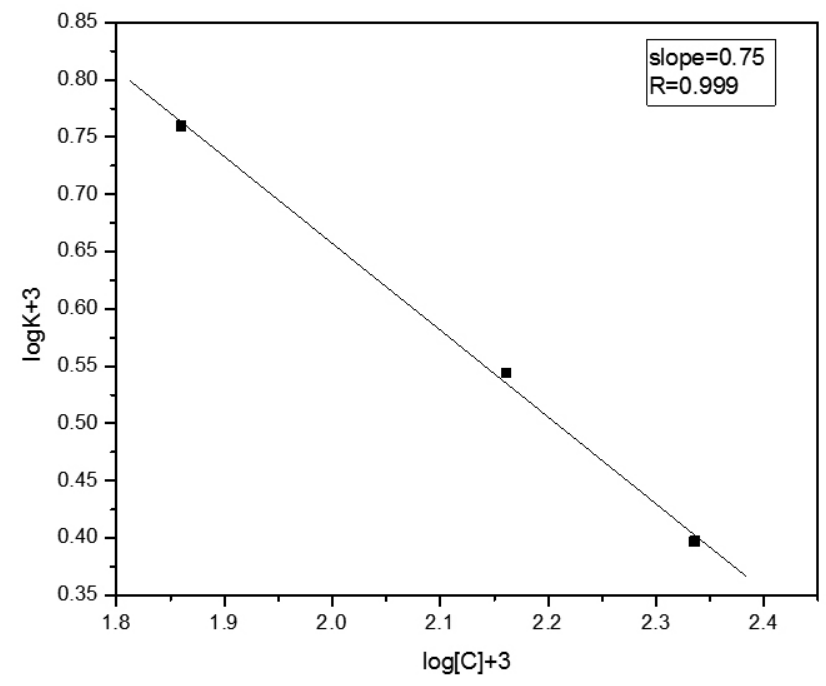

Figure 6. Effect of varying $\mathrm{NaClO}_{4}$ on reaction rate $[\mathrm{AMOX}]=3.0 \times 10^{-3}$ $\mathrm{mol} \mathrm{dm}{ }^{-3} ;[\mathrm{CAT}]=3.0 \times 10^{-4} \mathrm{~mol} \mathrm{dm}^{-3} ;[\mathrm{HCl}]=1.0 \times 10^{-4} \mathrm{~mol} \mathrm{dm}^{-3}$

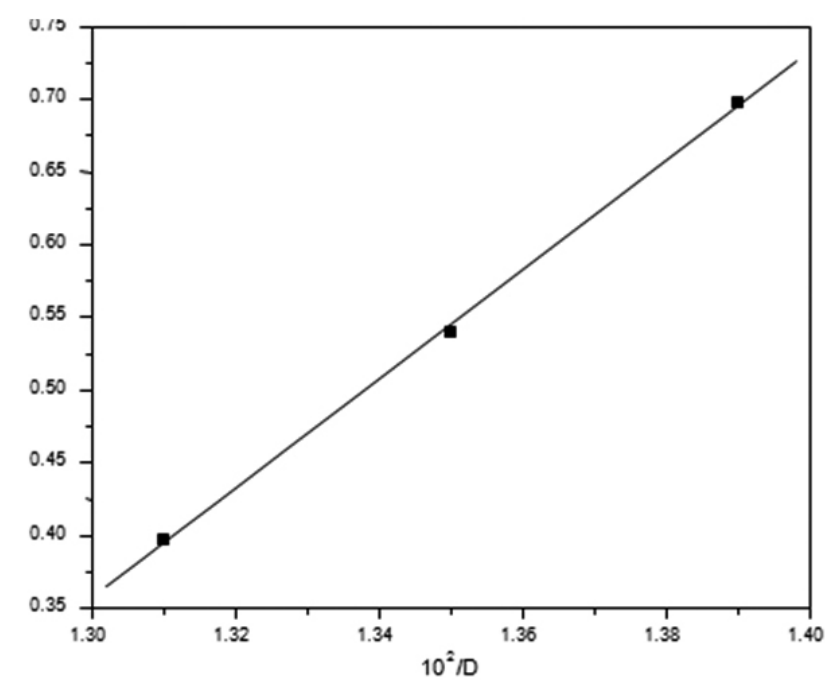

Figure 7. Plots of $\log \mathrm{K}$ vs $10^{2} / \mathrm{D}$. [AMOX] $=3.0 \times 10^{-3} \mathrm{~mol} \mathrm{dm}^{-3}$; [CAT] $=3.0 \times 10^{-4} \mathrm{~mol} \mathrm{dm}^{-3} ;[\mathrm{HCl}]=1.0 \times 10^{-4} \mathrm{~mol} \mathrm{dm}^{-3} ;\left[\mathrm{NaClO}_{4}\right]=0.145 \mathrm{~mol} \mathrm{dm}^{-3}$

Effect of chloride

The addition of chloride ions in the form of $\mathrm{NaCl}\left(1.0 \times 10^{-2}\right.$ to $\left.2.0 \times 10^{-2} \mathrm{M}\right)$ showed a slight increase in the reaction rate. This shows an approximately zero order dependence on $\left[\mathrm{Cl}^{-}\right]$.

\section{Effect of Temperature}

Keeping all other conditions constant, the reaction temperature was varied in the range, 293-305 K, and the values of $\mathrm{k}$ were determined at each temperature (Table 3). The energy of activation corresponding to these constants was evaluated from the Arrhenius plot of log $\mathrm{k}$ versus 1/T (Fig. 8), and other activation parameters were also obtained as reported in Table 4.

Table 3. Effect of varying temperature.

\begin{tabular}{|c|c|}
\hline Temperature $(\mathrm{K})$ & $10^{3} \mathrm{k}\left(\mathrm{s}^{-1}\right)$ \\
\hline 293 & 1.0 \\
\hline 297 & 1.8 \\
\hline 299 & 2.3 \\
\hline 305 & 4.6 \\
\hline
\end{tabular}


Table 4. Values of activation parameters

\begin{tabular}{|c|c|}
\hline Parameter & Value \\
\hline$E a\left(\mathrm{~kJ}^{-1} \mathrm{~mol}^{-1}\right)$ & 77.645 \\
\hline$\Delta \mathrm{H}^{\sharp}\left(\mathrm{kJ}^{-1} \mathrm{~mol}^{-1}\right)$ & 75.154 \\
\hline$\Delta \mathrm{G}^{\#}\left(\mathrm{~kJ}^{-1} \mathrm{~mol}^{-1}\right)$ & 61.96 \\
\hline$\Delta \mathrm{S}^{\#}\left(\mathrm{JK}^{-1} \mathrm{~mol}^{-1}\right)$ & -46.72 \\
\hline $\log \mathrm{A}$ & 10.79 \\
\hline
\end{tabular}

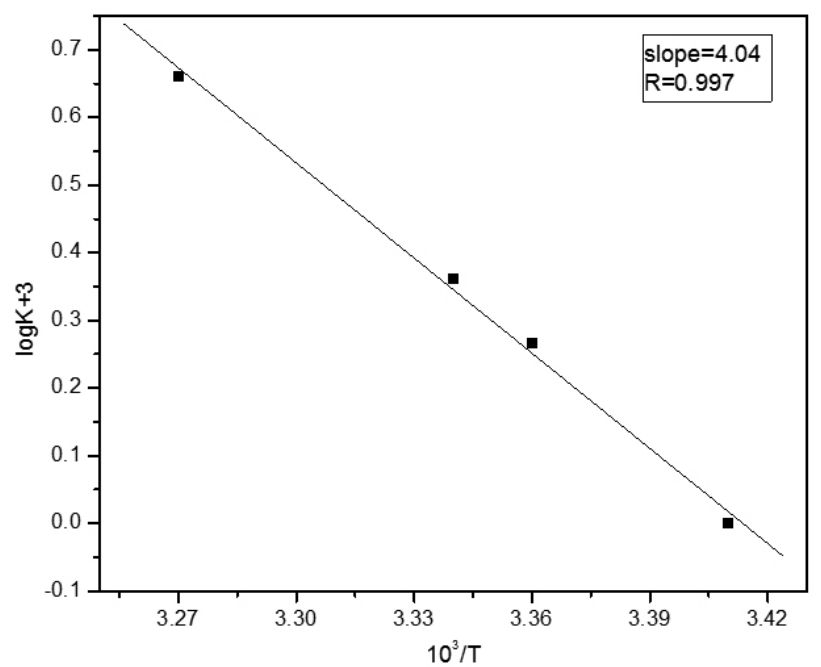

Figure 8. Arrhenius plot of logk versus $10^{3} / \mathrm{T}[\mathrm{AMOX}]=3.0 \times 10^{-3} \mathrm{~mol} \mathrm{dm}^{-3}$; $[C A T]=3.0 \times 10^{-4} \mathrm{~mol} \mathrm{dm}^{-3} ;[\mathrm{HCl}]=1.0 \times 10^{-4} \mathrm{~mol} \mathrm{dm}^{-3} ;\left[\mathrm{NaClO}_{4}\right]=0.141 \mathrm{~mol} \mathrm{dm}^{-3}$

\section{DISCUSSION}

Chloramines- $\mathrm{T}$ behaves as strong electrolyte in aqueous solutions. Depending on $\mathrm{pH}$ of the medium, CAT furnishes different types of reactive species in solution [16]. Many researchers have shown the existence of similar equilibria in acid and alkaline solutions of $N$ metallo- $N$ - halloarylsulphonamides [17-19]. CAT behaves as a strong electrolyte in aqueous solutions, forming different species as shown in equations (1.1) to (1.6) .

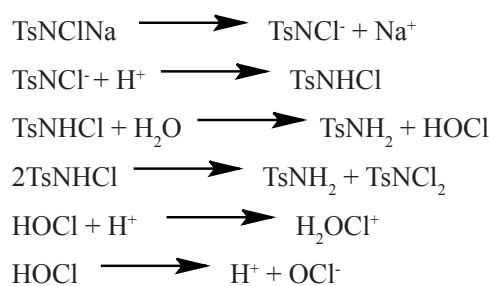

In alkaline solutions the expected reactive species in basic medium are TsNHCl, $\mathrm{HOCl}$, and TsNCl-. In acid solutions of CAT, the probable oxidizing species are the free acid (TsNHCl), dichloramine-T $\left(\mathrm{TsNHCl}_{2}\right), \mathrm{HOCl}$ and $\mathrm{H}_{2} \mathrm{OCl}^{+}$. Mohan et al., [16] have reported the formation of species of the type $\mathrm{TsNH}_{2} \mathrm{Cl}^{+}$.

$$
\mathrm{TsNHCl}+\mathrm{H}^{+} \longrightarrow \mathrm{TsNH}_{2} \mathrm{Cl}^{+}
$$

In the present case, the fractional order dependence on $\left[\mathrm{H}^{+}\right]$indicates that the protonation of TsNHCl results in formation of $\mathrm{TsNH}_{2} \mathrm{Cl}^{+}$which is likely to be the active species involved in the formation mechanism of reaction of Amoxicillin.

In view of the preceding discussion and experimental facts, Scheme 1 is proposed to explain the reaction mechanism for oxidation of Amoxicillin by CAT in acid medium.

$$
\begin{aligned}
& \mathrm{TsNHCl} \stackrel{\mathrm{K} 1}{\Leftrightarrow} \mathrm{TsNH}_{2} \mathrm{Cl}^{+} \\
& \mathrm{TsNH}_{2} \mathrm{Cl}^{+}+\mathrm{AMOX} \stackrel{\mathrm{K} 2}{\Leftrightarrow} \mathrm{X} \\
& \mathrm{X} \stackrel{\mathrm{K} 3}{\rightarrow} \mathrm{X}^{\prime}+\mathrm{TsNH}_{2} \\
& \mathrm{X}^{\prime} \stackrel{\mathrm{K} 4}{\rightarrow} \text { Product }
\end{aligned}
$$

Scheme 1. Detailed scheme for the oxidation of AMOX by CAT in acidic medium.

Based on Scheme 1 the total effective concentration of CAT is:

$$
\begin{aligned}
& {[\mathrm{CAT}]_{\mathrm{t}}=\left[\mathrm{TsNH}_{2} \mathrm{Cl}^{+}\right]+[\mathrm{TsNHCl}]+[\mathrm{X}]+\left[\mathrm{X}^{\prime}\right]} \\
& \mathrm{k}_{1}=\frac{\left[\mathrm{TsNH}_{2} \mathrm{Cl}^{+}\right]}{[\mathrm{TsNHCl}]\left[\mathrm{H}^{+}\right]} \\
& {[\mathrm{TsNHCl}]=\frac{\left[\mathrm{TsNH}_{2} \mathrm{Cl}^{+}\right]}{\mathrm{k}_{1}\left[\mathrm{H}^{+}\right]}} \\
& \mathrm{k}_{2}=\frac{[\mathrm{X}]}{\left[\mathrm{TsNH}_{2} \mathrm{Cl}^{+}\right][\mathrm{AMOX}]} \\
& {\left[\mathrm{TsNH}_{2} \mathrm{Cl}^{+}\right]=\frac{[\mathrm{X}]}{[\mathrm{AMOX}] \mathrm{k}_{2}}}
\end{aligned}
$$

Substituting Eq. 1.10 in Eq. 1.9

$$
\begin{array}{r}
{[\text { TsNHCl }]=\frac{[\mathrm{X}]}{\mathrm{k}_{1} \mathrm{k}_{2}[\mathrm{AMOX}]\left[\mathrm{H}^{+}\right]}} \\
\mathrm{k}_{3}=\frac{\left[\mathrm{TsNH}_{2}\right]\left[\mathrm{X}^{\prime}\right]}{[\mathrm{X}]} \\
{[\mathrm{X}]=\frac{\left[\mathrm{TsNH}_{2}\right]\left[\mathrm{X}^{\prime}\right]}{\mathrm{k}_{3}}}
\end{array}
$$

Substituting Eq. 1.12 in Eq. 1.10

$$
\left[\mathrm{TsNH}_{2} \mathrm{Cl}^{+}\right]=\frac{\left[\mathrm{TsNH}_{2}\right]\left[\mathrm{X}^{\prime}\right]}{[\mathrm{AMOX}] \mathrm{k}_{2} \mathrm{k}_{3}}
$$

Substituting Eq. 1.13 in Eq. 1.9

$$
[\mathrm{TsNHCl}]=\frac{\left[\mathrm{TsNH}_{2}\right]\left[\mathrm{X}^{\prime}\right]}{\mathrm{k}_{1} \mathrm{k}_{2} \mathrm{k}_{3}\left[\mathrm{AMOX}_{[}\left[\mathrm{H}^{+}\right]\right.}
$$

Substituting Eq. 1.12, 1.13 \& 1.14 in Eq. 1.8

$$
\left[\mathrm{CAT}_{t}\right]=\frac{\left[\mathrm{TsNH}_{2}\right]\left[\mathrm{X}^{\prime}\right]}{[\mathrm{AMOX}] \mathrm{k}_{2} \mathrm{k}_{3}}+\frac{\left[\mathrm{TsNH}_{2}\right]\left[\mathrm{X}^{\prime}\right]}{\mathrm{k}_{1} \mathrm{k}_{2} \mathrm{k}_{3}[\mathrm{AMOX}]\left[\mathrm{H}^{+}\right]}+\frac{\left[\mathrm{TsNH}_{2}\right]\left[\mathrm{X}^{\prime}\right]}{\mathrm{k}_{3}}+\left[\mathrm{X}^{\prime}\right]
$$

$\left[\mathrm{CAT}_{\mathrm{t}}\right]=\frac{\left[\mathrm{TsNH}_{2}\right]\left[\mathrm{X}^{\prime}\right]\left\{\mathrm{k}_{1}\left[\mathrm{H}^{+}\right]+1+\mathrm{k}_{1} \mathrm{k}_{2}[\mathrm{AMOX}]\left[\mathrm{H}^{+}\right]\right\}+\mathrm{k}_{1} \mathrm{k}_{2} \mathrm{k}_{3}[\mathrm{AMOX}]\left[\mathrm{H}^{+}\right]}{\mathrm{k}_{1} \mathrm{k}_{2} \mathrm{k}_{3}[\mathrm{AMOX}]\left[\mathrm{H}^{+}\right]}$

$$
\begin{gathered}
{\left[\mathrm{X}^{\prime}\right]=\frac{\mathrm{k}_{1} \mathrm{k}_{2} \mathrm{k}_{3}[\mathrm{AMOX}]\left[\mathrm{CAT}_{\mathrm{t}}\right]\left[\mathrm{H}^{+}\right]}{\left[\mathrm{TsNH}_{2}\right]\left\{1+\mathrm{k}_{1}\left[\mathrm{H}^{+}\right]+\mathrm{k}_{1} \mathrm{k}_{2}[\mathrm{AMOX}]\left[\mathrm{H}^{+}\right]\right\}+\mathrm{k}_{1} \mathrm{k}_{2} \mathrm{k}_{3}[\mathrm{AMOX}]\left[\mathrm{H}^{+}\right]}} \\
\text {From slow and rds of Scheme 1 }
\end{gathered}
$$

$$
\text { rate }=\mathrm{k}_{4}\left[\mathrm{X}^{\prime}\right]
$$

Substituting Eq. 1.16 in Eq. 1.15 
rate $=$

\section{$\frac{\mathrm{k}_{1} \mathrm{k}_{2} \mathrm{k}_{3} \mathrm{k}_{4}[\mathrm{AMOX}][\mathrm{CAT}]\left[\mathrm{H}^{+}\right]}{\left[\mathrm{TsNH}_{2}\right]\left\{1+\mathrm{k}_{1}\left[\mathrm{H}^{+}\right]+\mathrm{k}_{1} \mathrm{k}_{2}\left[\mathrm{AMOX}_{[}\left[\mathrm{H}^{+}\right]\right\}+\mathrm{k}_{1} \mathrm{k}_{2} \mathrm{k}_{3}[\mathrm{AMOX}]\left[\mathrm{H}^{+}\right]\right.}$}

The rate law is in good agreement with observed kinetic results.

Since Eq. (1.17) can be transformed into,

$$
\mathrm{k}^{\prime}=\frac{\text { rate }}{[\mathrm{CAT}]_{\mathrm{t}}}
$$

$\mathrm{k}^{\prime}=\frac{\mathrm{k}_{1} \mathrm{k}_{2} \mathrm{k}_{3} \mathrm{k}_{4}[\text { AMOX }]\left[\mathrm{H}^{+}\right]}{\left[\mathrm{TsNH}_{2}\right]\left\{1+\mathrm{k}_{1}\left[\mathrm{H}^{+}\right]+\mathrm{k}_{1} \mathrm{k}_{2}[\text { AMOX }]\left[\mathrm{H}^{+}\right]\right\}+\mathrm{k}_{1} \mathrm{k}_{2} \mathrm{k}_{3}[\text { AMOX }]\left[\mathrm{H}^{+}\right]}$

Activation parameters for the rate determining step (step (iv) of Scheme 1) were evaluated using the Arrhenius plot of $\log K_{4} K_{4}$ versus 1/T (Fig. 7). These data are presented in Table 4.

The reduction product of Oxidant, PTS had a retardation effect on the reaction rate indicating that $\mathrm{TsNH}_{2}$ is involved in a pre-equilibrium to the rate determining step. The effect of ionic strength on the rate can be understood essentially on the basis of ionic species involved in the rate limiting step [20].

The change in the solvent composition by varying the methanol content in methanol-water affects the reaction rate the effect of varying solvent composition on the reaction kinetics has been described in several publications $[21,22]$. Amis has shown that a plot of $\log \mathrm{k}_{\mathrm{C}}$ versus $1 / \mathrm{D}$ is linear with a negative slope for a reaction between a negative ion and a dipole or two dipoles, and with a positive slope for a positive ion-dipole interaction [23]. However, in the present study, an increase in the content of methanol in the reaction medium leads to the increase in the reaction rate, which is in agreement with Amis theory. The positive dielectric effect observed in the present studies clearly supports the suggested mechanism.

The proposed mechanism (Scheme 2) is further supported by the moderate values of energy of activation and other activation parameters. The high positive values of free energy of activation and enthalpy of activation indicate that the transition state is solvated, while the negative entropy of activation suggests the formation of transition state with less degree of freedom.

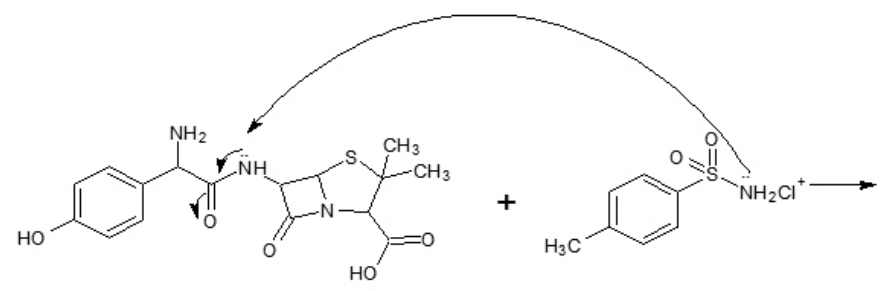

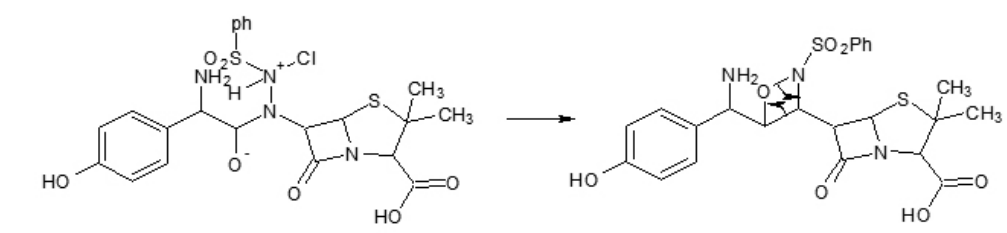

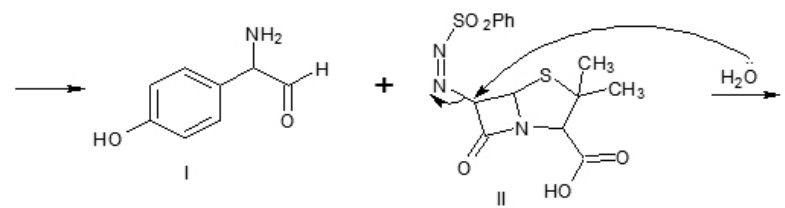<smiles>CC1(C)SC2C(O)C(=O)N2C1C(=O)O</smiles><smiles>Cc1ccc(S(N)(=O)=O)cc1</smiles>

Scheme 2. Detailed mechanism for the oxidation of AMOX by CAT in acidic medium.

\section{CONCLUSION}

The simplified kinetic study is consistent and gives a reasonable response to experimental data. The experimental results reveal that the rate of reaction is second order. The rate law is in conformity with all kinetic observations and the proposed mechanistic steps are supported by the negligible effect of ionic strength. For the title reaction it is concluded that $\mathrm{TsNH}_{2} \mathrm{Cl}^{+}$is the active species of CAT in acid medium. The overall sequence is consistent with the observed product, mechanistic and kinetic study.

\section{ACKNOWLEDGMENTS}

The authors wish to thank Dr. Krishna Venkatesh, Director \& Chief Technological Officer, Jain University, Bangalore for his invaluable suggestions and moral support.

\section{REFERENCES}

1. Indian Pharmacopoeia. 2, 701, (2007).

2. British Pharmacopoeia 1, 144, (2007).

3. European Department of Quality medicines In: European Pharmacopoeia $5,2925,(2005)$ 
4. United States Pharmacopoeia. 1402, (2007).

5. J. H. Mascher, C. Kikuta, J. Chromatgr. A, 812, 221, (1998).

6. J. I. Wibawa, D. Fowkes, P. N. Shaw, D. A. Barrett, J. Chromatogr. B Anal. Tech. Biomed. Life. Sci. 774, 141, (2002).

7. A. Menelaou, A. A. Somogyi, M. L. Barclay, F. Bochner, J. Chromatogr. B Biomed. Sci. Appl. 731, 261, (1999).

8. S. Z. Qureshi, T. Qayoom, M. I. Helalet, J. Pharm. Biomed. Anal. 21, 473, (1999).

9. A. K. Singh, R. Negi, B. Jain, Cat. Lett. 132, 285, (2009).

10. R. J. D. Saldanha, S. Ananda, X. Li, T. Shen, D. Wang, J. Mol. Str. 606, $147,(2002)$.

11. X. Li, T. Shen, D. Wang, J. Env. Sci. 24, 269, (2012).

12. A. Filiz, F. Kargi, J. Hazard. Mat. 179, 622, (2010).

13. V. K. Sharma, F. Liu, S. Tolan, M. Sohn, Chem. Eng. J. 221, 446, (2013).

14. L. Rizzo, S. Meric, M. Guida, D. Kassinos, V. Belgiorno, Water Res. 43 ,
4070, (2009).

15. R. S. Gujral, S. K. M. Haque, Int. J. Biomed. Sci. 6, 335, (2010).

16. K. Mohan, M. B. Jagadeesh, Ind. J. Chem. 47, 1226, (2008).

17. B. G. Pryde, F. G. Soper, J. Chem. Soc. 1514, (1931).

18. J. C. Morris, J. A. Salazar, M. A. Wineman, J. Am. Chem. Soc. 70, 2036, (1948).

19. E. Bishop, V. J. Jennings, Talanta 9, 581, (1962).

20. K. B. Sudha Rani, S. Ananda, N. M. Made Gowda, Amer. J. Chem. 3, 1, (2013).

21. R. M. Mulla, G. C. Hiremath, S. T. Nandibewoor, J. Chem. Sci. 117, 33, (2005)

22. S. A. Farokhi, S. T. Nandibewoor, Cat. Lett. 129, 207, (2009).

23. E. S. Amis, Solvent effects on reaction rates and mechanism. 1966. Academic, New York Press. 